食道癌患者に括けるシスプラチン投与後の腎機能の検討

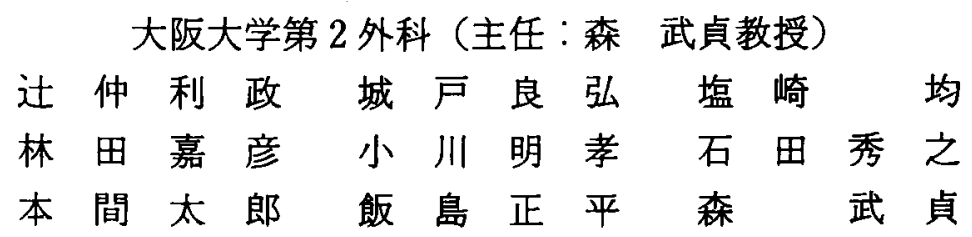

食道癌患者16例に対しシスプラチン (CDDP)を含む術前, 術後化学療法を行い, 計27 クールに打いて CDDP 投与後の各種腎機能の推移をモニターした. 腎障害予防のため大 量輸夜と利尿剤を併用したが, grade 2以上の腎障害の発生率は $37.5 \%$ \%っった。尿細管 障害が主体で，系球体機能障害は軽微であったが，2クール目には両者とも悪化がみら れた。低 $\mathrm{Na}$ 血症 ( $\leqq 130 \mathrm{mEq} / l)$ が $44 \%$ に出現し，これらのクレアチニンクリアランス は非低 Na 血症例よりも低下していた。 5 例において内分泌動態をモニターしたが， $\mathrm{CDDP}$ 投与後，アルドステロンの上昇，心房性 $\mathrm{Na}$ 利尿ベプキドの低下寸る傾向が認め られた。血中 $\mathrm{Na}$ 値低下および容量負荷の不十分性を反映していると考えられた。今後輸 液療法の改善（Na 投与量と輸液量の増加，代用血浆の併用）が必要である.

索引用語：食道癌, シスプラチン, 腎障害, 心房性 $\mathrm{Na}$ 利尿ペプチド, アルドステロン

\section{緒言}

シスプラチン(CDDP)は，扁平上皮癌に対しすぐれ た抗腫瘍効果が認められる反面強い腎障害を有してい る。腎毒性軽減の対策として，大量輸液と利尿凧の併 用 ${ }^{1)}$ ，チ才硫酸ナトリウム ${ }^{233)}$, 高張食塩水 ${ }^{4)}$, 次硝酸ビ スマス ${ }^{5) 6}$ の投与などが行われているが，腎障害発生の 完全制御は困難である.今回，当科において CDDPを 含む術前もしくは術後化学療法を施行した食道癌症例 について，腎障害の害態と病態について検討を加え， 今後改善すべき諸問題を明らかにしようと試みた。

\section{研究対象と方法}

対象：対象症例は，1987年 1 月より1990年11月まで の期間当科にて取り扱った食道癌患者のうち, CDDP を含む化学療法を施行した16例（徒前化学放射線療法 5 例，術啳補助化学療法11例）で表 1 にその背景因子 を示した，対象例の全身状態の指標である PS(performance status）はPSO（無症状で活動制限のない状 熊)：8 例，PS1 (軽度の症状があるが，軽作業は可能 な状態)；8例であった。化学療法は 2 クール(4週間 間隔)を原則としたが，3例においては1クールのみ となった。総計27クールに対して CDDP 投与後の腎機

1991年 1月16日受付 1991年 9 月 24 日採用

\section{表 1 食道癌患者背景}

\begin{tabular}{|c|c|c|c|}
\hline \multicolumn{2}{|l|}{ 患者数：16例 } & \multicolumn{2}{|c|}{ PS (performance status) } \\
\hline \multirow{2}{*}{\multicolumn{2}{|c|}{ 齢: $: 55.8 \pm 7.2$ 歳 $($ 平均 $\pm S D)$}} & 0 & 8例 \\
\hline & & 1 & 8例 \\
\hline \multicolumn{2}{|l|}{ 化学療法 } & 施行前腎譏能(Ccr) & \\
\hline \multicolumn{2}{|l|}{ 術前放射線化学療法 } & $\sim 80$ & 10例 \\
\hline \multirow[t]{2}{*}{ 放射線 $+\mathrm{CDDP}+5 \mathrm{FU}$} & 5 例 & $80 \sim 60$ & 3例 \\
\hline & & $60 \sim 40$ & 3例 \\
\hline \multicolumn{4}{|l|}{ 㭪後補助化学療法 } \\
\hline $\mathrm{CDDP}+5 \mathrm{FU}$ & 2 例 & & \\
\hline $\mathrm{CDD}+\mathrm{PEP}+5 \mathrm{FU}$ & 9 例 & & \\
\hline
\end{tabular}

CDDP : cisplatin, $5 \mathrm{FU}$ : fluorouracil, PEP : pepleomycin

能の推移をモニターした。 また 5 例において化学療法 前後の

血中レニン活性 (PRA), 正常値0.3 3.0ng $/ \mathrm{ml} / \mathrm{h}$, アルドステロン (ALD), 正常値 $2 \sim 140 \mathrm{ng} / \mathrm{dl}$, ハジプレッシン $(\mathrm{ADH})$, 正常値 $0.3 \sim 3.5 \mathrm{pq} / \mathrm{ml}$, 心房性 $\mathrm{Na}$ 利尿ペプチド (ANP), 正常值29〜74pg/ $\mathrm{ml}$, の変化を測定した. ANP および $\mathrm{ADH}$ は, SRL 社 にて, PRA と ALD は，当院中央検查室にて湘定した。 CDDP 投与法：全症例, 完全静脈栄盖 (TPN) 施行 下 $(2,000 \mathrm{ml} / \mathrm{day})$ にて化学療法を行った。CDDP 投 与当日は, $1,000 \mathrm{ml}$ の pre-hydration ののち $70 \sim 100$ 
$\mathrm{mg} / \mathrm{m}^{2}$ の CDDPを 1 ～時間にて点滴静注し，その 後 $500 \mathrm{ml}$ の追加補液を行った。投与後 7 日間は 2,000 $\mathrm{ml} / \mathrm{day}$ の尿量を確保するよう輸液負荷を行い, 必要 に応じてラシックス、マニトール等の利尿剤の投与を 行った。制哣剤として CDDP 投与当日にメトクロプラ シド10A/日を投与し，必要に応じてデキサメサジンを 追加投与した。

腎機能検查：腎機能のパラメータとして，尿量，血 中 $\mathrm{Na}, \mathrm{BUN}$, クレтチニン $(\mathrm{Cr}), \beta_{2}$ microgloburin (BMG), 浸透圧(Osm), 尿中 $\mathrm{Na}, \mathrm{UN}, \mathrm{Cr}, \mathrm{BMG}$, $\mathrm{N}$-acetyl-D-glucosaminidase(NAG), Osm を測定し, クレアチニンクリアランス（Ccr；尿 $\mathrm{Cr} /$ 血 $\mathrm{Cr} \times$ 尿 量 $\mathrm{ml} / \mathrm{m}$ ), 異常值 $<80 \mathrm{ml} / \mathrm{m}$,

functional excretion of $\mathrm{Na}(\mathrm{FENa}$; 尿 $\mathrm{Na} /$ 血 $\mathrm{Na} \times$ 血 $\mathrm{Cr} /$ 尿 $\mathrm{Cr} \times 100$ ), 異常値 $>1 \%$

functional excretion of BMG (FEBMG ; 尿 BMG/ 血 $\mathrm{BMG} \times$ 血 $\mathrm{Cr} /$ 尿 $\mathrm{Cr} \times 100$ ), 異常値 $>0.13 \%$

$\mathrm{NAG}$ Index（尿 $\mathrm{NAG} /$ 尿 $\mathrm{Cr}$ ), 異常値 $>5 \mathrm{u} / \mathrm{g}$

自由尿クリアランス $\left(\mathrm{CH}_{2} \mathrm{O}\right.$; 尿量 $\mathrm{ml} / \mathrm{m} \times(1$ 尿 Osm/血Osm)), 異常値 $<|0.5| \mathrm{ml} / \mathrm{m}$, を計算した。 データは平均士SDにて表示し, 統計学的処理のため には unpaired Student t-testを用い，5\%以下を有意
差ありと判定した。化学療法時の副作用の判定には, WHOの規準を用いた。

\section{成 䋶 \\ I. CDDP 投与後の腎機能の推移}

$\mathrm{CDDP}$ 投与によると考えられる腎障害の出現頻度 は，WHO 規準に基づいて判定すると，grade 1(BUN 26 40, Cr 1.6 3.0, Ccr 69 50) 5 例 (31\%), grade 2 (BUN 41 60, Cr 3.1 5.0, Ccr 49 30) 4 例( $25 \%$ ), grade 3 (BUN 61 60, Cr 5.1 8.0, Ccr $<24$ ) 2 例 (12.5\%) であった. Grade 2の 4 例は全例施行前腎機 能は正常であったが, Grade 3の 2 例はともにCDDP 投与前に grade 2 の腎障害を有していた. Grade 1の一 部症例を除いて，ほとんどが Ccr の異常に基づいてい た.

\section{1）米球体機能}

$\mathrm{Ccr}$, 血中 $\mathrm{Cr}$ 拈よび BMG 值を腎系球体の指標とし て用い, その変化を図 1 に示した. Ccr は，1クール目 0〜1日に上昇したのち 7 - 8 日目に平均 72.8 と低下 した。 2 クール目には 7〜8日目61.7とその低下が強 かった，Crは，1クール目ほぼ一定であり，2クール 目徐々に上昇したが正常域に留まっていた。 BMGは， 1クール目ほぼ一定であったが，2クール目に上昇が

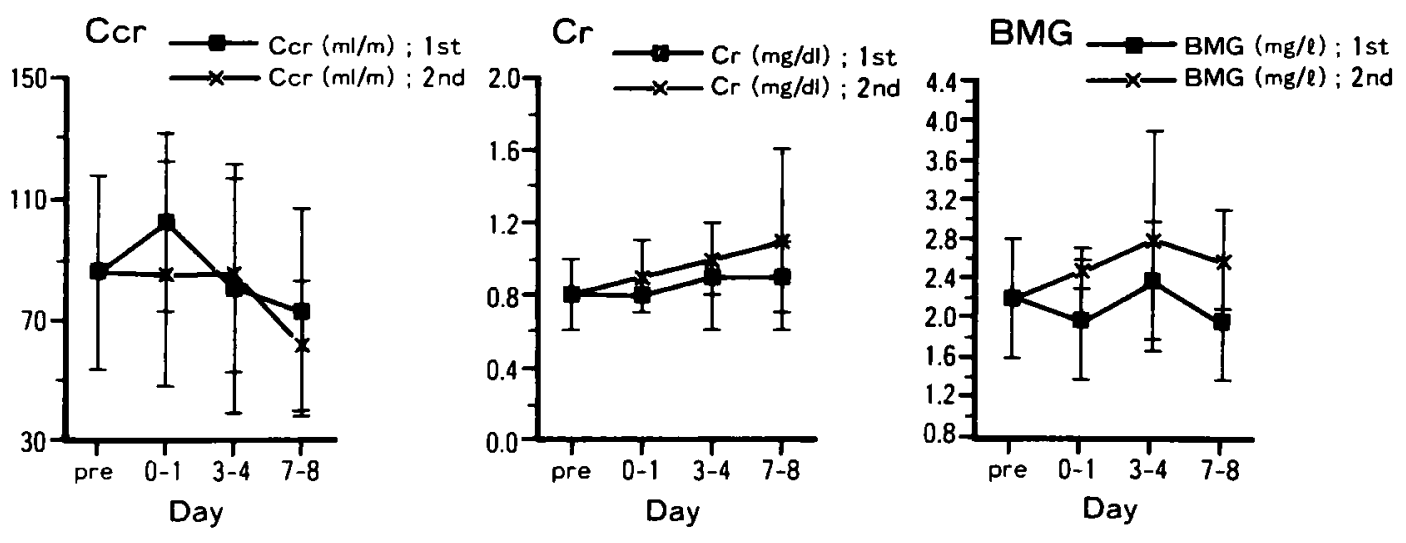

図 1 CDDP 投与後の堅釆球体機能の推移
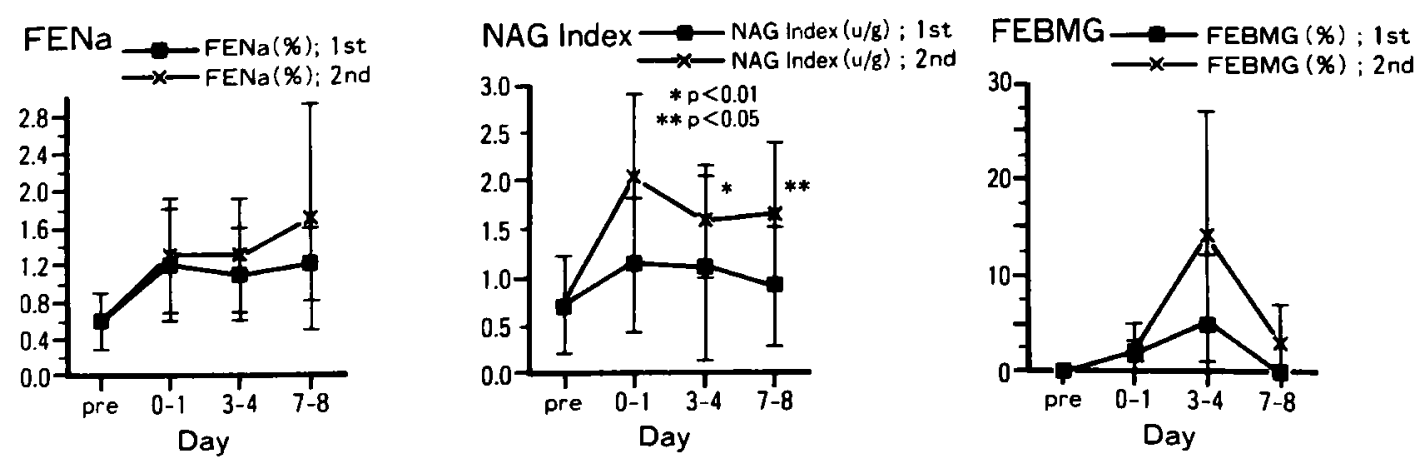

図 2 CDDP 投与後の堅尿細管機能の推移 
みられた。 2 クール目に系球体機能異常が出現した。

2）尿細管機能

尿細管機能として FENa，NAG Index, FEBMG を 用い，CDDP 投与後の推移を図 2 に示した。 FENa は，

1,2 クールとも投与直後 $(0 \sim 1$ 日) 上り $1 \%$ 以上 之異常値を呈した. NAG Index も, 同様 1，2クール とも投与直後 $(0 \sim 1$ 日) 上り10以上と異常を呈し, とくに2 クール目では $3 \sim 4$ 日， $7 \sim 8$ 日目に前值と 比較し有意の上昇がみられた. FEBMG と 1，2クー ルとも投与直後より $0.13 \%$ 以上の異常值を呈してい た。いずれの指標も，2クール目の変化が強かった。 一方腎㖪質機能の指標として $\left|\mathrm{CH}_{2} \mathrm{O}\right|$ の推移を調查 したが，その平均値は CDDP 投与後すべて0.5以上と 正常であり，2症例で一過性の異常出現をみたのみで あった。

II. 低 $\mathrm{Na}$ 血症

$\mathrm{CDDP}$ 投与後 $130 \mathrm{mEq} / l$ 以下の低 $\mathrm{Na}$ 血症の出現を 16例中 7 例 (44\%) に認めた。 7 例の血中 $\mathrm{Na}$ 值の推移 を図 3 に示した。 $\mathrm{Na}$ 値は，投与後 $3 \sim 4$ 日目から 7 〜8日目にかけて最低値となった。いずれも血中 $\mathrm{Na}$ 低值, 尿中 $\mathrm{Na}$ 排出量高值であり，一見 $\mathrm{ADH}$ 異常分泌 症 (SIADH) と類似していた。しかし低 $\mathrm{Na}$ 血症例に おける Ccr 最底值は43.6土16.2であり，非低 $\mathrm{Na}$ 血症 例（9 例）の值65.2 222.2 と比較し有意に低下してい た. 一方尿細管機能の指標としての FENa はそれぞれ $1.63 \pm 0.9 ， 1.83 \pm 1.2$ とともに低下して拈り，差をみ なかった。それゆえ腎障害のより強い症例（とくに尿 細管障害に乐球体機能低下を合併して例）に低 $\mathrm{Na}$ 血 症例が出現していたことが判明した。また 2 例におい

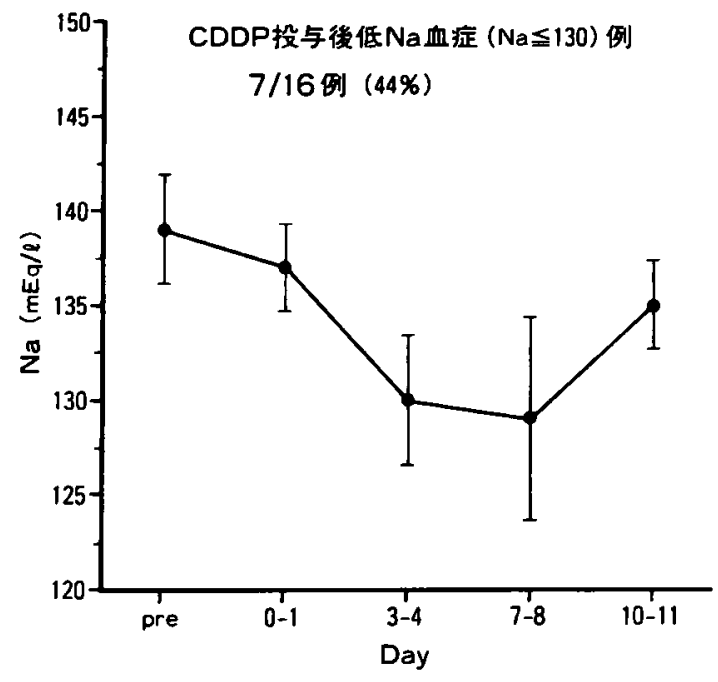

图 3 低 $\mathrm{Na}$ 血症例における血中 $\mathrm{Na}$ 值の推移

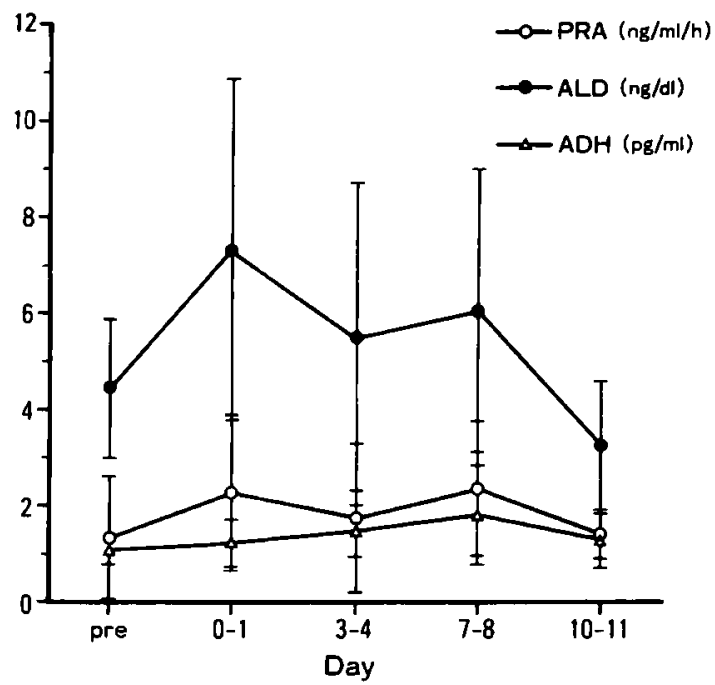

図 4 CDDP 投与後の各種ホルモン变動（5 例）

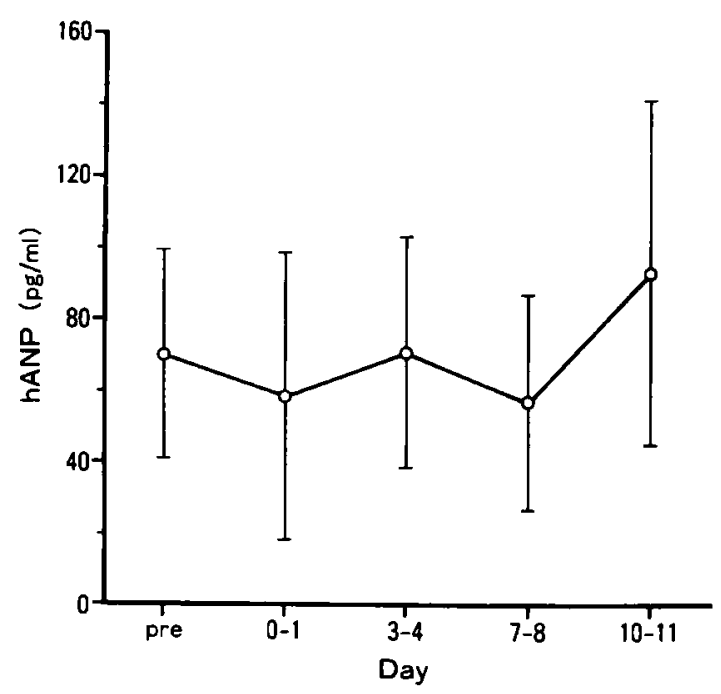

図 5 CDDP 投与後の血中 ANP 变動

て血中 ADH の推移を調査したが，いずれも正常域で あった。

\section{CDDP 投与後の内分泌変動}

CDDP 投与後, 血中 PRA, ALD, ADH, ANP の推 䔟を 5 例においてモ二ターした，図 4 に示したごとく PRA と ADH は投与前後で変動を認めなかったが, ALD は直後 $(0 \sim 1$ 日) より上昇し， $7 \sim 8$ 日に至る まで持続した。測定を行った 5 例中, 低 $\mathrm{Na}$ 血症を呈し たものが 2 例あり, ALDの上昇は血中 $\mathrm{Na}$ 值の低下に 反応していた可能性が考えられた。一方 ANP は, 図 5 に示したごとく輸液負荷にもかかわらず，0１日目 よりやや低下し，7－8 日目までその低下が持続し， その後回復した。

\section{考 察}

CDDP による腎障害の病態として, GFR の低下, 尿 
細管再吸收障害がもたらされ7，いわゆる polyuric renal failure の状態影が生じる，その対策として大量 輸液を行って GFR を維持し，多尿状態を保持したま ま腎機能の回復を待つことは，理にかなった治療法で ある。この輸液負荷療法によって，実際に腎障害が生 じる頻度を食道癌患者を対象として，今回調査を行っ た. WHO 規準で grade 2 以上の腎障害が $37.5 \%$ に発 生していた。食道癌を対象とした報告がみられないた め比較し得なかったが肺癌を対象とした報告")(Cr 2.5 以上 $17 \%)$ p卯巣癌を対象とした報告4) (Cr 2以上 $32 \%)$ と比較し，高頻度であった，対象とした食道癌患者の 全身状態が不良であったことがその原因の一つであっ たと推定された，腎障害の内容を倹討すると，系球体 機能は1クール目には活とんど影響を受けなかった が，2クール目に低下する傾向が認められた。一方尿 細管機能は，1クール目より異常を呈し，2クール目 にその異常は著しかった。いずれの变化も可逆的であ ク，ほぽ 2 週間後には前値のレベルに回復した。しか しながら，CDDPを計5クール投与した1例で5クー ル終了後軽度ではあるが不可逆性の腎障害が出現した ため，従来の輸液療法は反復投与時の腎障害の制御に 限界があると考えられた。補助療法として，1989年以 前の 4 症例で次硝酸ビスマス3g 3 日間の前投与, 1989 年以降の 4 症例に対しウリナスタチン20万単位/日を CDDP 投与前日より 5 日間投与を行った。しかしいず れも特記すべき効果は認められず，補助療法としての 有用性を確認出来なかった。 しかし当科での次硝酸ビ スマスの投与量は，有效性を報告した例5) における投

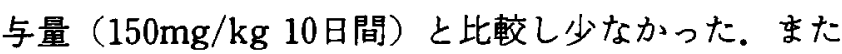
ウリナスタチンの当科に拈ける投与量も有效性を報告 した例9)での投与量（30万単位 5 日間）と比較し少な かったため，これらの補助療法が無効であるという結 論は得られなかった。

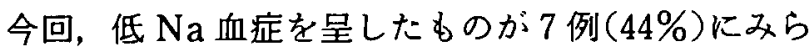
れたため, その成因を調べた所, 低 $\mathrm{Na}$ 血症例では尿細 管障害に加えて系球体機能す低下していた。 $\mathrm{CDDP}$ 投与前の C cr が70以下の症例が5/7例を占めて いた。低 $\mathrm{Na}$ 血症にもかかわらず尿中 $\mathrm{Na}$ 排泄が多く， 一見 SIADH 様の病態であったため， 2 例で血中 $\mathrm{ADH}$ の推移をモニターしたが，上昇はみられず，その 本体は全く異なっていた。それゆえ CDDP 投与による $\mathrm{Na}$ 喪失性腎症に伴弓低 $\mathrm{Na}$ 血症時に, SIADH に対す るよらに水制限を行うことは腎機能を考慮すると禁忌 であり，反対に投与 $\mathrm{Na}$ 量と輸液負荷を増加させ，場合
によってはドーパミン等を使用し, GFR の改善が必要 であると考えられた． 5 例に拁いて，血中 PRA，ALD， $\mathrm{ADH}$ ，の測定を行ったが ALDの上昇が認められ，血 中 $\mathrm{Na}$ の低下に反応した結果であると推測された。

ANP は心房由来の生理活性物質であり，心房の伸 展刺激により分泌され，尿量と $\mathrm{Na}$ 排泄を增加させ $る^{(10)}$ ．実際 ANP 投与により，GFR が著しく上昇す る(1)ことから，CDDPによる腎障害に対して ANP 投 与が有効礼であることが報告されている，従来行われ てきた大量輸液療法に扰いて，大量輸夜による容量負 荷によって心房が伸展され内因性 ANPが上昇した結 果, 腎障害を軽減したのではないかと仮定し，血中 ANPの測定を行った。しかしながら血中ANPは CDDP 投与後低下し，10１1日目に前值へと復㷌する 傾向が認められた。このことは，今回用いた輸液負荷 では内因性 ANPの上昇をもたらすには不十分であ ク，CDDP 投与に伴う多尿によりかえって循環血装量 としては減少していることを意味している。それゆえ ANP 分泌を誘導し, 前述した低 $\mathrm{Na}$ 血症を防止し, 腎 機能を保持するためには，十分の $\mathrm{Na}$ 投与とより多量 の輸液を行らか, 血㓡や代用血浆製剤の補給を行って, 血管内容量の維持を計る必要があると考えられた。

\section{結語}

$\mathrm{CDDP}$ 含む化学療法時の腎障害の病態について調 査した。尿細管障害が主体で，反復投与により腎障害 の程度が強まった，今回用いた輸夜量では，容量負荷 として十分とは言いえず，今後 $\mathrm{Na}$ 拈よび輸液投与量 の増加や代用血浆剂の併用を計る必要がある。

\section{文献}

1) De Jager R, Longeval E, Klastersky J : Highdose cisplatin with fluid and mannitol-induced diuresis in advanced lung cancer: A phase II clinical trial of the EORTC lung cancer working party (Balgium). Cancer Treat Rep $64: 1341$ $-1346,1980$

2) Howell SB, Taetle R: Effect of sodiumthiosulfate on cis-dichlorodiammineplatium (II) toxicity and antitumor activity in L1210 leukemia. Cancer Treat Rep 64:611-616, 1980

3）広沢彰, 酒井茂利, 飯塚和弘他：Cisdichlorodiammineplatinum (II)の全身投与によ る腎機能の影響と sodiumthiosulfate 併用の効 果, 癌と化療 $14: 2870-2875,1987$

4) Ozols RF, Ostchego Y, Myers CE, et al: High- 
dose cisplatin in hypertonic saline in refractory ovarian cancer. J Clin Oncol $3: 1246-1251,1985$

5）森川利昭, 河村栄二, 小宮山貴子他：次硝酸ビスマ ス大量投与法によるシスプラチンの副作用軽減効 果とビスマスおよびプラチナの薬動力的検討，日 癌治療会誌 $25: 1138-1145,1990$

6) 陳 瑞東, 黒川賀重, 中山一武他：次硝酸ビスマス による cisplatinの毒性軽減に関する臨床的検討, 特に腎毒性軽減効果について，日産婦会誌 39 ： 815-822, 1987

7) Chopra S, Kaufman JS, Jones TW, et al: Cis-diamminodichloroplatinum-induced acute renal failure in the rat. Kidney Int $21: 54-64$, 1982
8) Capasso G, Anastasio P, Giordano D, et al : Beneficial effects of atrial natriuretic factor in the rat. Am J Nephrol $7: 228-234,1987$

9）荒川敦志, 加藤律子, 浅井英和他 : Cisplatinum $の$ 腎毒性に対する urinastatinの効果, 癌と化療 $17: 2229-2234,1990$

10) De Bold AJ, Borenstein HB, Veyress AT, et al: $A$ rapid and potent natriuretic response to intravenous injection of atrial myocardial extract in rats. Life Sci $28: 89-94,1981$

11) Huang CL, Lewicki J, Johnson LK, et al: Renal mechanism of action of rat natriuretic factor. J Clin Invest $75: 769-773,1985$

\title{
A STUDY OF RENAL FUNCTIONS AFTER THE ADMINISTRATION OF CISPLATIN IN ESOPHAGEAL CANCER PATIENTS
}

\author{
Toshimasa TSUJINAKA, Yoshihiro KIDO, Hitoshi SHIOZAKI, Yoshihiko HAYASHIDA, \\ Akitaka OGAWA, Hideyuki ISHIDA, Taro HOMMA, \\ Shohei IIIMA and Takesada MORI \\ Department of Surgery, II, Osaka University Medical School
}

Cisplatin including pre- and postoperative chemotheropy was carried out in 16 esophageal cancer patients and various renal functions were monitored after cisplatin administration in total 27 courses. Nephrotoxicity ( $\geqq$ grade 2 ) occurred in $37.5 \%$ of the cases inspite of massive fluid load with diuretics. Renal tubular dysfunction was the main body of nephrotoxicity by cisplatin, accompanied by mild glomerular dysfunction. Both functions were aggravated in the second course of chemotherapy. Hyponatremia ( $\geqq 130 \mathrm{mEq} / \mathrm{l})$ was observed in $44 \%$ of the cases, of which creatinine clearance was worse than that of non-hyponatremic cases. Plasma hormonal changes were monitored in five cases, where aldosteron tended to increase and atrial natriuretic peptide tended to decrease after cisplatin administration. Decrease in serum natrium and insufficient fluid load were conceived to be its reason. It is necessary to improve the infusion therapy regarding to a dose of sodium administration, infusion volume, and administration of plasma expander. 